
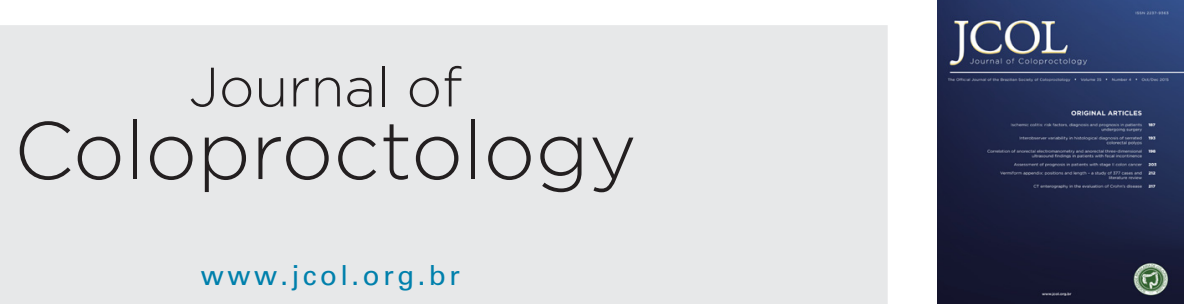

Original Article

\title{
Evaluating the effect of gentamicin-clindamycin lavage on post-operational pain and infection through laparoscopic colectomy surgery
}

\author{
Alireza Negahi ${ }^{a}$, Amirhossein Arminfar $^{b}$, Hamed Vaseghi $^{b}$, Mohammad Moradi $^{c}$, \\ Mahdi Alemrajabi (1) ${ }^{d, *}$ \\ a Iran University of Medical Sciences, Rasool Akram Hospital, Department of General Surgery, Tehran, Iran \\ $\mathrm{b}$ Iran University of Medical Sciences, Tehran, Iran \\ c Iran University of Medical Sciences, Firoozgar Clinical Research Development Center, Tehran, Iran \\ d Iran University of Medical Sciences, Firoozgar Clinical Research Development Center, Firoozgar Hospital, Tehran, Iran
}

\section{A R T I C L E I N F O}

Article history:

Received 26 July 2019

Accepted 15 September 2019

Available online 27 October 2019

Keywords:

Laparoscopic colectomy

Antibiotic peritoneal lavage

Intra-abdominal infection

Wound infection

Peritoneal lavage

\begin{abstract}
A B S T R A C T
Introduction: Peritoneal antibiotic or normal saline lavage is seen to be beneficial in order to reduce the pain or infection risk through laparoscopic surgeries. It can also be applied for laparoscopic colectomy surgeries. In this study, we have compared the effects of antibiotic solution lavage (gentamycin-clindamycin) with normal saline lavage in patients undergoing laparoscopic colectomy surgery.

Method: In this double-blind Randomized Controlled Trial (RCT), 40 patients undergoing laparoscopic colectomy surgery were divided into antibiotic and normal saline lavage groups (20 patients in each group). Post-operational pain, need for painkiller, white blood cells count, C-reactive protein level, duration of hospitalization and wound infection were compared in 30 days between the groups.

Results: Antibiotic lavage group had significantly less pain than the normal saline group $(\mathrm{p}<0.05)$ through $3,6,12$ and $24 \mathrm{~h}$ after surgery. C-reactive protein level, white blood cells count, painkiller use, and hospitalization duration were significantly lower in antibiotic group. However, there was no difference regarding wound or intra-abdominal infection between the both groups.

Conclusion: Using gentamicin-clindamycin peritonea lavage helps patients undergoing laparoscopic colectomy surgery in pain reduction, need for painkillers and hospitalization duration.

(c) 2020 Sociedade Brasileira de Coloproctologia. Published by Elsevier Editora Ltda. This is an open access article under the CC BY-NC-ND license (http://creativecommons.org/ licenses/by-nc-nd/4.0/).
\end{abstract}

\footnotetext{
* Corresponding author.

E-mail: alemrajabi.m@iums.ac.ir (M. Alemrajabi).

https://doi.org/10.1016/j.jcol.2019.09.007

2237-9363/@ 2020 Sociedade Brasileira de Coloproctologia. Published by Elsevier Editora Ltda. This is an open access article under the CC BY-NC-ND license (http://creativecommons.org/licenses/by-nc-nd/4.0/).
} 


\title{
Avaliação do efeito da lavagem com gentamicina-clindamicina sobre a dor e a infecção após colectomia laparoscópica
}

\author{
R E S U M O
}

Palauras-chave:

Colectomia laparoscópica

Lavagem peritoneal com

antibiótico

Infecção intra-abdominal

Infecção de feridas

Lavagem peritoneal
Introdução: A lavagem peritoneal com antibiótico ou com soro fisiológico normal é benéfica para reduzir o risco de dor ou de infecção durante cirurgias laparoscópicas, além de poder ser aplicada também em colectomias laparoscópicas. Neste estudo, comparamos os efeitos da lavagem com solução antibiótica (gentamicina-clindamicina) e da lavagem com solução salina normal em pacientes submetidos à colectomia laparoscópica.

Método: Neste Ensaio Clínico Randomizado (ECR), controlado e duplo-cego, 40 pacientes submetidos à colectomia laparoscópica foram divididos em dois grupos (20 pacientes em cada grupo) para receberem antibiótico ou solução salina normal. Dor pós-operatória, necessidade de analgésico, contagem de leucócitos, nível de proteína C-reativa, tempo de internação e infecção da ferida foram comparados entre os grupos em 30 dias.

Resultados: De forma significativa, o Grupo Antibiótico apresentou menos dor que o Grupo Salina Normal $(p<0,05)$ em 3, 6, 12 e 24 horas após a cirurgia. O nível de proteína C-reativa, a contagem de leucócitos, o uso de analgésicos e o tempo de internação foram significativamente menores no Grupo Antibiótico. Porém, não houve diferença em relação à infecção da ferida ou intra-abdominal entre os dois grupos.

Conclusão: O uso da lavagem peritoneal com gentamicina-clindamicina ajuda a reduzir a dor, a necessidade de analgésicos e o tempo de internação de pacientes submetidos à colectomia laparoscópica.

C 2020 Sociedade Brasileira de Coloproctologia. Publicado por Elsevier Editora Ltda. Este é um artigo Open Access sob uma licença CC BY-NC-ND (http://creativecommons.org/ licenses/by-nc-nd/4.0/).

\section{Introduction}

In spite of recent advances in surgery techniques, antimicrobial treatments, and intensive cares, there are still high mortality rates related to secondary peritonitis, following abdominal surgeries. ${ }^{1}$ Intra-Operative Peritoneal Lavage (IOPL) is one of the methods used to reduce the infectious risk. ${ }^{2}$ Beside the necessary studies for IOPL benefits and potential side effects, there is still a dilemma about the material being used for the lavage.

A 2005 study asked 153 surgeons to fill a questionnaire about using IOPL and $97 \%$ of them claimed that they have used this method. About $61 \%$ of them kept lavage until the liquid becomes clear, $17 \%$ had used $500-1000 \mathrm{~mL}$ of liquid for IOPL and $20 \%$ of them used more than one liter. ${ }^{3}$ As abdominal infection control consists of using systemic antibiotic, source control, and aspirating wound contaminations, there is no definite evidence to show IOPL effect on controlling abdominal infections. $^{4}$

Peritoneal lavage consists of using variable amounts of a liquid, usually normal saline, in order to washout the peritoneal cavity. ${ }^{5}$ It is believed that peritoneal lavage can washout the microorganisms, as well as inflammatory cytokines and blood from the peritoneal cavity, which can improve the inflammatory state and decrease the growth rate of the bacteria. $^{6}$

It is now reported that Gentamicin-Clindamycin Lavage (GCL) after elective colorectal surgeries can improve survival in patients with colorectal tumors. ${ }^{7}$ In patients undergoing axillary lymph node dissection, gentamicin lavage and clindamycin lavage both could decrease daily lymph drainage in comparison with saline lavage. Also half of patients in saline lavage group had positive results for bacterial culture, which was significantly more than the gentamicin group, which was $5 \% .^{7,8}$ It is also reported that GCL can decrease the Surgery Site Infection (SSI), and intra-abdominal abscesses in patients undergoing surgery for colorectal cancer. ${ }^{9}$ The mortality of $48.9 \%$ in saline lavage cases, and $16.4 \%$ in antibiotic cases have reported in meta-analysis which emphasizes antibiotic lavage importance in acute peritonitis cases. ${ }^{1}$

In this study, effects of GCL and saline lavage are compared in patients undergoing laparoscopic colectomy regarding their pain, painkiller need, hospitalization duration and inflammatory markers.

\section{Methods}

\section{Patients and settings}

In this double-blinded randomized controlled trial, we selected 40 patients undergoing laparoscopic colectomy from March 2017 until March 2018 in Firoozgar hospital affiliated to Iran University of medical sciences, Tehran, Iran. Patients were selected using a random number table, generated using a computer. The sample size was 20 according to Ruiz-Tovar and colleagues study. ${ }^{10}$

The selected patients were divided into two groups of Normal Saline Lavage (NSL) and GCL. As a double-blinded study neither the surgeon, nor the resident visiting patients after the operation knew the content of the lavage bottles.

The process was already described to the patients and their consent was taken. All the recorded information was anonymized to keep the patients' privacy and the 
methodology of the study were approved by the university ethical committee.

\section{Lavage application}

In both groups, lavage was applied just before closing the surgery site, using 500 milliliters of a solution with suctionirrigation machine. Lavage was maintained in abdominal cavity for $3 \mathrm{~min}$ and then suctioned.

NSL group's lavage solution was 500 milliliters of sterile saline, and GCL group's was $240 \mathrm{mg}$ of gentamicin and $600 \mathrm{mg}$ of clindamycin, dissolved in 500 milliliters of the same sterile saline.

No painkillers were given to the patients in the first $3 \mathrm{~h}$, unless they were complaining for severe pain.

Pain was measured using Visual Analogue Scale (VAS), an array of 10 pictures visualizing from "no pain" to "the worst pain ever", after $3,6,12$, and $24 \mathrm{~h}$ by a last-year surgical resident.

\section{Post operation data collection and statistical analysis}

A checklist was prepared for each patient and all the required data were filled by the same resident.

Data was analyzed using SPSS 22.0 software. Differences were compared using t-test, Mann-Whitney U test, and ChiSquared test for qualitative variables. The correlations were also investigated using Pearson's correlation coefficient and Spearman's rank correlation.

\section{Results}

Forty patients entered this trial, 20 in NSL group and 20 in GCL group.

After three hours of the operation, the NSL group had the mean pain score of $4.8( \pm 1.3)$ while GCL had the score of 3.4 $( \pm 1.2)$ ( $p$-value $=0.0011)$. The same pattern was seen until the 24th hour that NSL group had the score of $3.7( \pm 0.64)$ and GCL group the score of $2.6( \pm 0.81)$ (p-value $<0.0001)$.

After three hours, 14 patients from NSL group needed Apotel but only 8 of GCL group needed such painkiller ( $p$ value $=0.06$ ).

Overall, GCL group received less painkiller $(1.75 \mathrm{~g} \pm 0.72$ for Apotel and $0.3 \mathrm{mg} \pm 0.57$ for Pethidine) than NSL group ( $2.4 \mathrm{~g} \pm 0.60$ for Apotel and $1.9 \mathrm{mg} \pm 4.5$ for Pethidine) after $24 \mathrm{~h}$ (p-value of 0.004 for Apotel and 0.12 for Pethidine).

After $12 \mathrm{~h}, \mathrm{WBC}$ count and CRP levels were measured from both groups. Mean WBC count was 12.8 per. $\mathrm{mm}^{3}( \pm 1.9)$ in NSL group and $10.5 \mathrm{~mm}^{3}( \pm 1.4)$ in GCL ( $p$-value $\left.=0.0001\right)$. CRP levels were also measured as low, intermediate and high. GCL group had better situation than the NSL group in CRP levels. Mean hospital stay was $4.65( \pm 0.67)$ days in NSL group, whereas GCL group had mean hospital stay of $4.2( \pm 0.41)$ $(p$-value $=0.014)$.

One of the patients in NSL group had wound infection in our one-month follow-up. The same proportion was seen in GCL group and one of them had wound infection after one month.

\section{Discussion}

Nowadays, laparoscopic colectomy is spreading daily and pain and infectious, as two main complications of these procedures, should be investigated carefully for postoperation patients. Prophylaxis antibiotic, systemic antibiotic therapy, antibiotic lavage and normal saline lavage are considered as approaches for reducing post-operational infections. ${ }^{11}$

CRP, an acute-phase reactant, is considered as an accurate diagnosis factor for SSI beside procalcitonin. ${ }^{12}$ In our study, GCL Group had lower levels of CRP in comparison with control (NSL Group) so that it might be considered as an effective approach to reduce the risk of infection.

Park and colleagues had previously reported that those receiving antibiotic lavage had less pain and needed less time for recovery. ${ }^{13}$ We also had less pain in our antibiotic group and also less painkiller, Apotel and Pethidine, was needed in antibiotic group. They had also shorter hospital stay and had lower WBC counts and CRP levels, as two inflammatory and infection diagnostic markers.

In spite of recent works on SSI incidence rate following antibiotic lavage, there was no significant difference in our study. SSI was reported to be decreased following axillary surgery and laparoscopic sleeve gastrectomy. ${ }^{7,9,14}$ On the other hand, there are studies reporting the same SSI distribution between antibiotic and control group following sleeve gastrectomy. ${ }^{15}$ We had one SSI in NSL and one in GCL group, which might be due to our small study size. Larger studies and wide meta-analysis are needed for conclusive results.

It seems to be rational to consider antibiotic lavage a potentially valuable approach for decreasing post-operational complications such as inflammation, pain and maybe wound infection. Moreover, antibiotic lavage in sleeve gastrectomy has been shown to lower post-operative transaminase concentrations (AST and ALT) in those undergoing antibiotic lavage. ${ }^{7,16}$

Considering current evidence, antibiotic lavage can be considered as a useful approach in various surgeries, especially laparoscopic colectomy. Further studies with larger groups and more careful investigations are necessary for drawing more reliable conclusions.

\section{Conflicts of interest}

The authors declare no conflicts of interest.

\section{REFERENCES}

1. Qadan M, Dajani D, Dickinson A, Polk HC. Meta-analysis of the effect of peritoneal lavage on survival in experimental peritonitis. Br J Surg. 2010;97:151-9.

2. Edmiston CE, Leaper DJ. Intra-operative surgical irrigation of the surgical incision: what does the future hold-saline, antibiotic agents, or antiseptic agents? Surg Infect (Larchmt). 2016;17:656-64. 
3. Whiteside OJH, Tytherleigh MG, Thrush S, Farouk R, Galland $\mathrm{RB}$. Intra-operative peritoneal lavage - who does it and why? Ann R Coll Surg Engl. 2005;87:255-8.

4. Platell C, Papadimitriou JM, Hall JC. The influence of lavage on peritonitis. J Am Coll Surg. 2000;191:672-80.

5. Jergens ME. Peritoneal lavage. Am J Surg. 1977;133:365-9.

6. Adam U, Ledwon D, Hopt UT. Programmed lavage as a basic principle in therapy of diffuse peritonitis. Langenbecks Arch Chir. 1997;382 4 Suppl 1:S18-21.

7. Ruiz-Tovar J, Llavero C, Gamallo C, Santos J, Calpena R, Arroyo A, et al. Effect of peritoneal lavage with

clindamycin-gentamicin solution during elective colorectal cancer surgery on the oncologic outcome. Surg Infect (Larchmt). 2016;17:65-70.

8. Oller I, Ruiz-Tovar J, Cansado P, Zubiaga L, Calpena R. Effect of lavage with gentamicin vs. clindamycin vs. physiologic saline on drainage discharge of the axillary surgical bed after lymph node dissection. Surg Infect (Larchmt). 2015;16:781-4.

9. Ruiz-Tovar J, Santos J, Arroyo A, Llavero C, Armañanzas L, López-Delgado A, et al. Effect of peritoneal lavage with clindamycin-gentamicin solution on infections after elective colorectal cancer surgery. J Am Coll Surg. 2012;214: 202-7.

10. Ruiz-Tovar J, Llavero C, Muñoz JL, Zubiaga L, Diez M. Effect of peritoneal lavage with clindamycin-gentamicin solution on post-operative pain and analytic acute-phase reactants after laparoscopic sleeve gastrectomy. Surg Infect (Larchmt). 2016;17:357-62.

11. Briggs A, Goldberg J. Tips, tricks, and technique for laparoscopic colectomy. Clin Colon Rectal Surg. 2017;30:130-5.

12. Simon L, Gauvin F, Amre DK, Saint-Louis P, Lacroix J. Serum procalcitonin and C-reactive protein levels as markers of bacterial infection: a systematic review and meta-analysis. Clin Infect Dis. 2004;39:206-17.

13. Park YH, Kang H, Woo YC, Park SG, Baek CW, Jung YH, et al. The effect of intraperitoneal ropivacaine on pain after laparoscopic colectomy: a prospective randomized controlled trial. J Surg Res. 2011;171:94-100.

14. Ruiz-Tovar J, Cansado P, Perez-Soler M, Gomez MA, Llavero C, Calero P, et al. Effect of gentamicin lavage of the axillary surgical bed after lymph node dissection on drainage discharge volume. Breast. 2013;22:874-8.

15. Baker DM, Jones JA, Nguyen-Van-Tam JS, Lloyd JH, Morris DL, Bourke JB, et al. Taurolidine peritoneal lavage as prophylaxis against infection after elective colorectal surgery. Br J Surg. 1994;81:1054-6.

16. Kotake Y, Takeda J, Matsumoto M, Tagawa M, Kikuchi H. Subclinical hepatic dysfunction in laparoscopic cholecystectomy and laparoscopic colectomy. Br J Anaesth. 2001;87:774-7. 